\title{
Attenuation of Nicotine-Induced Antinociception, Rewarding Effects, and Dependence in $\mu$-Opioid Receptor Knock-Out Mice
}

\author{
Fernando Berrendero, ${ }^{1}$ Brigitte L. Kieffer, ${ }^{2}$ and Rafael Maldonado ${ }^{1}$ \\ ${ }^{1}$ Laboratori de Neurofarmacologia, Facultat de Ciéncies de la Salut i de la Vida, Universitat Pompeu Fabra, 08003 \\ Barcelona, Spain, and ${ }^{2}$ Institut de Génétique et de Biologie Moléculaire et Cellulaire, Centre National de la Recherche \\ Scientifique/Institut National de la Santé et de la Recherche Médicale/Université Louis Pasteur, BP 16367404 Illkirch, \\ France
}

The involvement of $\mu$-opioid receptors in different behavioral responses elicited by nicotine was explored by using $\mu$-opioid receptor knock-out mice. The acute antinociceptive responses induced by nicotine in the tail-immersion and hot-plate tests were reduced in the mutant mice, whereas no difference between genotypes was observed in the locomotor responses. The rewarding effects induced by nicotine were then investigated using the conditioning place-preference paradigm. Nicotine produced rewarding responses in wild-type mice but failed to produce place preference in knock-out mice, indicating the inability of this drug to induce rewarding effects in the absence of $\mu$-opioid receptors. Finally, the somatic expression of the nicotine withdrawal syndrome, precipitated in dependent mice by the injection of mecamylamine, was evaluated. Nicotine withdrawal was significantly attenuated in knock-out mutants when compared with wild-type mice. In summary, the present results show that $\mu$-opioid receptors are involved in the rewarding responses induced by nicotine and participate in its antinociceptive responses and the expression of nicotine physical dependence.

Key words: nicotine; opioid; knock-out mice; withdrawal; conditioning place preference; reward
Nicotine is one of the active components in tobacco smoke and appears to play a major role in tobacco addiction (Crooks and Dwoskin, 1997). This compound affects different aspects of behavior such as locomotion, nociception, anxiety, learning, and memory, and it produces several behavioral responses related to its addictive properties such as rewarding effects and physical dependence (Decker et al., 1995). The pharmacological effects of nicotine are mediated by the activation of nicotinic acetylcholine receptors (nAChRs), which are members of the superfamily of ligand-gated ion channels (Dani, 2001). nAChRs are located mainly at a presynaptic level and their activation increases the release of dopamine (Pontieri et al., 1996), noradrenaline (Clarke and Reuben, 1996), acetylcholine (Wilkie et al., 1993), glutamate (McGehee et al., 1995), and GABA (Yang et al., 1996).

The endogenous opioid system has been reported to participate in several central effects of nicotine (Balfour, 1982). Thus, the stimulation of nAChRs increases the synthesis and release of met-enkephalin in mouse striatum (Dhatt et al., 1995), and an enhancement on preproenkephalin mRNA levels in rat striatum and hippocampus has been also reported after acute nicotine and during nicotine withdrawal (Houdi et al., 1998). In addition, endogenous opioids have been implicated in the reinforcement of smoking because the administration of the opioid antagonists naloxone and naltrexone modulates cigarette consumption and the subjective pleasure derived from smoking (Karras and Kane,

\footnotetext{
Received April 30, 2002; revised Sept. 17, 2002; accepted Sept. 26, 2002.

This work has been supported by grants from Plan Nacional Sobre Drogas, European Communities BIOMED2 (98-2227), Human Frontier Science Program Organization (RG0077/2000-B), Generalitat de Catalunya (Research Distinction), and Laboratorios Dr. Esteve.

Correspondence should be addressed to Rafael Maldonado, Laboratori de Neurofarmacologia, Facultat de Ciéncies de la Salut i de la Vida, Universitat Pompeu Fabra, C/Doctor Aiguader 80, 08003 Barcelona, Spain. E-mail: rafael.maldonado@cexs.upf.es. Copyright (C) 2002 Society for Neuroscience $0270-6474 / 02 / 2210935-06 \$ 15.00 / 0$
}

1980; Wewers et al., 1998). However, the possible cross-reactivity of these antagonists with other receptors complicates the interpretation of these data (Almeida et al., 2000; Tome et al., 2001). Furthermore, several behavioral and physiological effects, including antinociception, rewarding properties, and dependence (Decker and Meyer, 1999; Hildebrand et al., 1999; Watkins et al., 2000) are shared by nicotine and opioids. Three different opioid receptors $\mu, \delta$, and $\kappa$, have been identified and cloned (Kieffer, 1999). $\mu$-Opioid receptors have been reported to be responsible for the addictive properties of opioids (Matthes et al., 1996; Hutcheson et al., 2001) and to be involved in the rewarding properties of other drugs of abuse, such as alcohol (Roberts et al., 2000) and cannabinoids (Ghozland et al., 2002).

The present study was designed to evaluate the possible involvement of $\mu$-opioid receptors in several behavioral responses of nicotine by using $\mu$-opioid receptor knock-out mice (Matthes et al., 1996). For this purpose, we first studied locomotor and antinociceptive effects induced by acute nicotine administration in $\mu$-opioid receptor knock-out mice and their wild-type littermates. We also investigated the rewarding properties of nicotine by using the conditioning place-preference paradigm and the development of physical dependence after chronic nicotine treatment in both mutant and wild-type mice.

\section{MATERIALS AND METHODS}

Animals. The generation of mice lacking $\mu$-opioid receptors has been described previously (Matthes et al., 1996). Mice were housed five per cage in a temperature-controlled room $\left(21 \pm 1^{\circ} \mathrm{C}\right)$ with a $12 \mathrm{hr}$ light/dark cycle (lights between 8 A.M. and 8 P.M.). Food and water were available ad libitum. Mice were habituated to their new environment and handled for 1 week before the experimental procedure was started. The mice (8-12 weeks old) used in this study were on a C57/BL6 genetic background. These were obtained from hybrid mutant mice originally created on a 129 SVJ-C57/BL6 background (Matthes et al., 1996) by backcrossing breeding over 10 generations. In each experimental group, mice were 
matched for age and sex. Animal procedures were conducted in accordance with the guidelines of the European Communities Directive 86/ $609 /$ EEC regulating animal research and approved by the local ethical committee. The observer was blind to genotype and treatment in all the experiments.

Drugs. (-)-Nicotine hydrogen tartrate salt [(-)-1-methyl-2(3-pyridyl) pyrrolidine] and mecamylamine hydrochloride (Sigma, Madrid, Spain) were dissolved in physiological saline $(0.9 \%)$ and administered by subcutaneous route in a volume of $10 \mathrm{ml} / \mathrm{kg}$.

Locomotor activity. The locomotor responses induced by nicotine hydrogen tartrate salt $(0.5,0.7,1$, and $3 \mathrm{mg} / \mathrm{kg}$, s.c. $)$ or saline administration were measured by using individual locomotor activity boxes $(9 \times 20 \times 11$ $\mathrm{cm}$; Imetronic) as reported previously (Castañé et al., 2002).

Tail-immersion and hot-plate tests. The tail-immersion test was measured $15 \mathrm{~min}$ after nicotine hydrogen tartrate salt ( 1 and $3 \mathrm{mg} / \mathrm{kg}$, s.c.) or saline administration as described previously (Simonin et al., 1998). The water temperature was maintained at $50 \pm 0.5^{\circ} \mathrm{C}$ using a thermoregulated water-circulating pump (Clifton, North Somerset, UK). The trial was terminated once the animal flicked its tail. In the absence of tail flick, a $15 \mathrm{sec}$ cutoff was used to prevent tissue damage.

The hot-plate test was performed as described previously (Simonin et al., 1998) $16 \mathrm{~min}$ after nicotine hydrogen tartrate salt (1 and $3 \mathrm{mg} / \mathrm{kg}$, s.c.) or saline injection. The heated surface of the plate was kept at a temperature of $52 \pm 0.1^{\circ} \mathrm{C}$ (Columbus Instruments, Columbus, $\mathrm{OH}$ ). The nociceptive threshold evaluated was the jumping response. In absence of jumps, a $240 \mathrm{sec}$ cutoff was used to prevent tissue damage.

The data obtained were expressed as absolute values (see Table 1) and as percentage of maximum possible effect (see Fig. 2) using the following equation $(\mathrm{MPE} \%)=($ test latency - control latency $) /($ cutoff time control latency) $\times 100$.

Conditioning place preference. The rewarding effects of nicotine were evaluated by using the conditioning place-preference paradigm as described recently (Castañé et al., 2002). The apparatus consisted of two main square conditioning compartments separated by a triangular central division. During the preconditioning phase, each mouse was placed in the middle of the central division and had free access to both compartments of the conditioning apparatus for $18 \mathrm{~min}$, with the time spent in each compartment recorded. Treatments were counterbalanced between compartments to use an unbiased procedure. No initial place preference or aversion for the different compartments was observed in the experiment. For the conditioning phase, mice were treated during $8 \mathrm{~d}$ with alternate injections of nicotine hydrogen tartrate salt $(0.5,0.7$, and 1 $\mathrm{mg} / \mathrm{kg}$, s.c.) or saline. Mice were confined to the corresponding compartment immediately after injection for $20 \mathrm{~min}$. Nicotine was administered on days $1,3,5$, and 7 , and saline was administered on days $2,4,6$, and 8 . Control animals received saline every day. The test phase was conducted as in the preconditioning phase, i.e., free access to both compartments for $18 \mathrm{~min}$, and the time spent in each compartment was recorded. A score was calculated for each mouse as the difference between test and preconditioning time spent in the drug-paired compartment.

Nicotine dependence and withdrawal. Nicotine dependence was induced by using Alzet osmotic minipumps (Model 2001; Alzet, Cupertino, CA) as reported previously (Castañé et al., 2002). These minipumps, implanted subcutaneously under brief ether anesthesia, contained saline or nicotine solutions and delivered a constant subcutaneous flow at a rate of $1 \mu \mathrm{l} / \mathrm{hr}$. The concentration of nicotine was adjusted to compensate for differences in body weights of the mice. Thus, the average-weighed mice received a dose of $\sim 10 \mathrm{mg} \cdot \mathrm{kg}^{-1} \cdot \mathrm{d}^{-1}$ nicotine hydrogen tartrate salt during $6 \mathrm{~d}$. Nicotine withdrawal syndrome was precipitated $6 \mathrm{~d}$ after minipump implantation by injection of the nicotinic receptor antagonist, mecamylamine $(1 \mathrm{mg} / \mathrm{kg}$, s.c.). The somatic signs of withdrawal were evaluated immediately after mecamylamine injection during a period of $30 \mathrm{~min}$, as reported previously (Castañé et al., 2002). The number of wet dog shakes, front paw tremors, and scratches was counted. Body tremor, ptosis, teeth chattering, genital licks, and piloerection were scored 1 for appearance or 0 for nonappearance within each 5 min time. The locomotor activity over $5 \mathrm{~min}$ periods was rated 0,1 , or 2 ( 0 for inactivity, 1 for low activity, and 2 for normal activity). A global withdrawal score was calculated for each animal by giving each individual sign a relative weight, as reported previously (Castañé et al., 2002).

Statistical analysis. Results in all experiments were compared by using a between subjects two-way ANOVA (genotype and treatment as factors of variation). Individual treatment effects in each group (mutant and wild-type) were analyzed using one-way ANOVA between subjects. Post hoc comparisons were made when required by using Dunnett's test after

\section{A Horizontal locomotor activity}

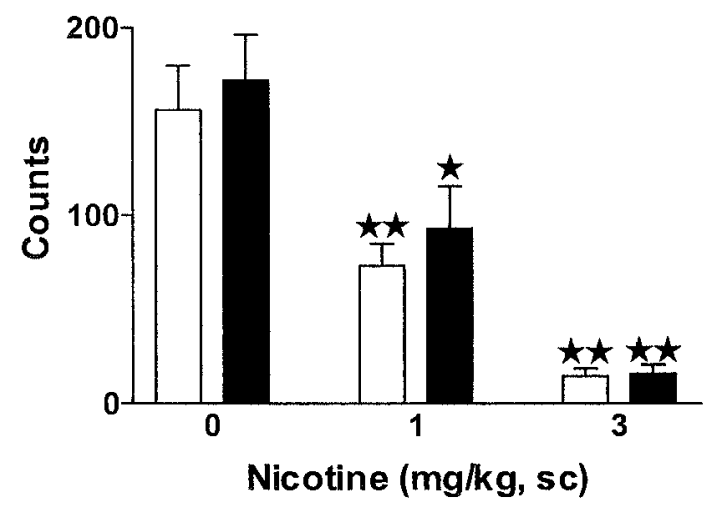

B Vertical locomotor activity

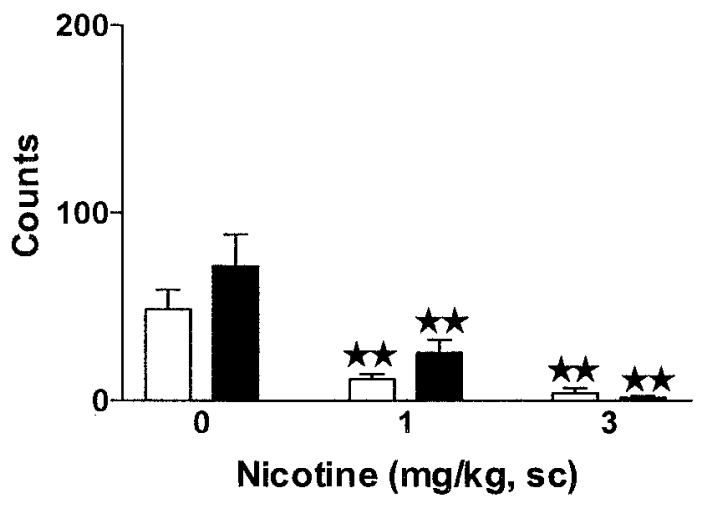

Figure 1. Effects of acute nicotine on locomotion in $\mu$-opioid receptor knock-out and wild-type mice. Horizontal $(A)$ and vertical $(B)$ locomotion were measured $5 \mathrm{~min}$ after nicotine administration $(0,1$, and 3 $\mathrm{mg} / \mathrm{kg}$, s.c.). Data are expressed as mean \pm SEM of photocell counts during a $10 \mathrm{~min}$ period in wild-type (white bars) and knock-out (black bars) mice $\left(n=10\right.$ mice for each group). ${ }^{\star} p<0.05 ;{ }^{\star \star} p<0.01$ when comparing with saline group of the same genotype (Dunnett test).

significant main effects of treatment by one-way ANOVA. Differences were considered significant if the probability of error was $<5 \%$.

\section{RESULTS}

\section{Nicotine decreased locomotion in wild-type and $\boldsymbol{\mu}$-opioid receptor knock-out mice}

On days 1, 2, and 3, animals were exposed to the locomotor activity boxes to be habituated to the test environment (data not shown), and acute effects of nicotine ( 1 and $3 \mathrm{mg} / \mathrm{kg}$, s.c.) were evaluated on day 4. Nicotine decreased locomotion in $\mu$-opioid receptor knock-out mice and wild-type littermates (Fig. 1). Twoway ANOVA revealed a significant effect of treatment on the horizontal activity $\left(F_{(2,54)}=35.73 ; p<0.0001\right)$ but not effect of genotype $\left(F_{(1,54)}=0.72 ; \mathrm{NS}\right)$ or interaction between treatment and genotype $\left(F_{(2,54)}=0.16 ; \mathrm{NS}\right)$. Subsequent one-way ANOVA (treatment) indicated a significant effect of treatment in wild-type $\left(F_{(2,27)}=21.04 ; p<0.0001\right)$ and knock-out mice $\left(F_{(2,27)}=15.99\right.$; $p<0.0001)$. Post hoc analysis showed a similar decrease of horizontal activity when nicotine was administered in wild-type 
(1 and $3 \mathrm{mg} / \mathrm{kg}: p<0.01)$ and $\mu$-opioid receptor knock-out mice (1 mg/kg: $p<0.05 ; 3 \mathrm{mg} / \mathrm{kg}: p<0.01)$ (Fig. $1 A)$.

Two-way ANOVA also revealed a significant effect of treatment on the vertical activity $\left(F_{(2,54)}=22.76 ; p<0.0001\right)$, without effect of genotype $\left(F_{(1,54)}=2.58\right.$; NS) or interaction between these two factors $\left(F_{(2,54)}=1.08\right.$; NS). One-way ANOVA revealed significant effect of treatment in wild-type $\left(F_{(2,27)}=13.88 ; p<\right.$ $0.0001)$ and knock-out mice $\left(F_{(2,27)}=11.21 ; p<0.001\right)$. Post hoc comparisons showed a similar reduction of vertical activity in both genotypes at the doses of nicotine used ( 1 and $3 \mathrm{mg} / \mathrm{kg} ; p<$ 0.01) (Fig. 1B).

In an additional experiment, locomotor effects induced by lower doses of nicotine were evaluated (data not shown). Nicotine administered at the dose of $0.7 \mathrm{mg} / \mathrm{kg}$ (s.c.) also induced a similar decrease of locomotor activity in wild-type and knock-out mice as revealed by two-way ANOVA on horizontal (treatment: $F_{(1,34)}=$ $12.34, p<0.01$; genotype: $F_{(1,34)}=0.38$, NS; interaction: $F_{(1,34)}=$ 0.15 , NS) and vertical (treatment: $F_{(1,34)}=8.35, p<0.01$; geno-
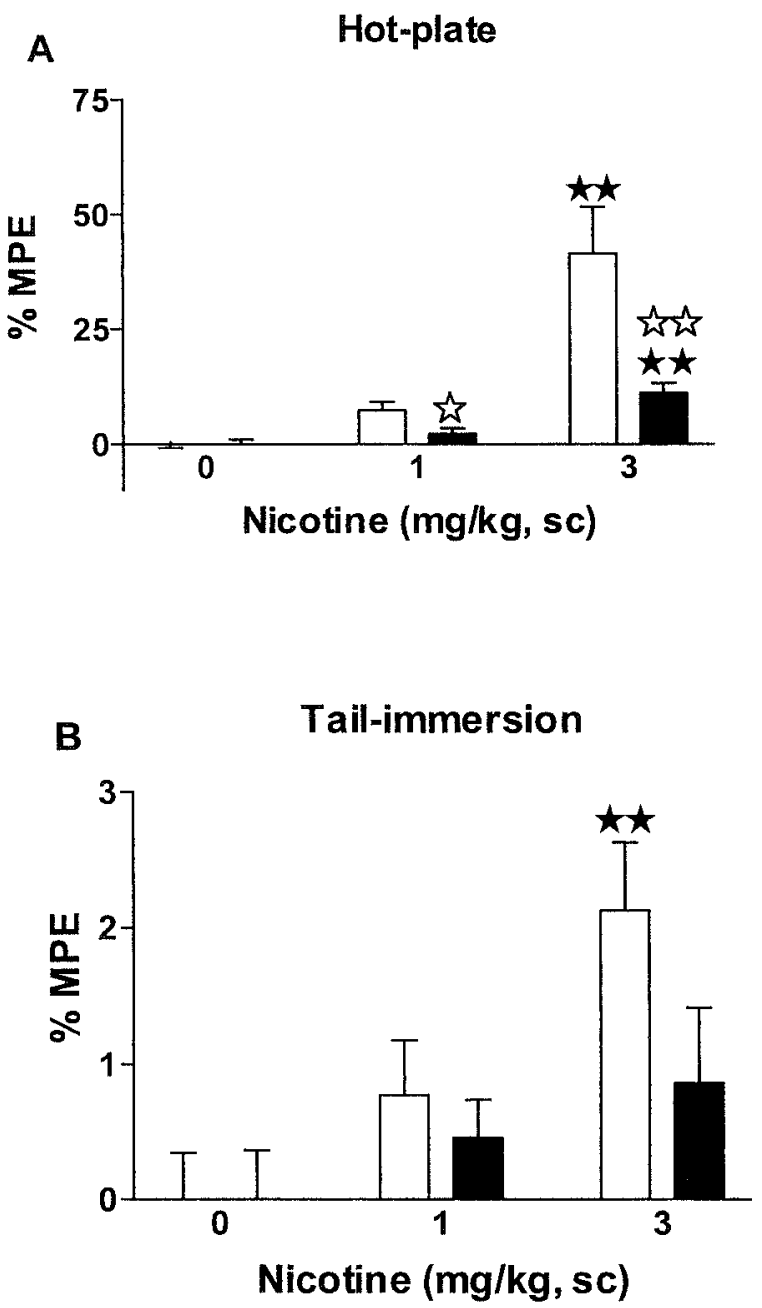

Figure 2. Antinociceptive effects of acute nicotine in $\mu$-opioid receptor knock-out and wild-type mice. Antinociceptive responses in the hot-plate $(A)$ and tail-immersion $(B)$ tests were measured 15 and 16 min, respectively, after nicotine administration $(0,1$, and $3 \mathrm{mg} / \mathrm{kg}$, s.c.). Data are expressed as mean \pm SEM of percentage of maximum possible effect in wild-type (white bars) and knock-out (black bars) mice $(n=10$ mice for each group). ${ }^{\star \star} p<0.01$ when comparing with saline group of the same genotype. ${ }^{x} p<0.05 ;{ }^{2} p<0.01$ when comparing between genotypes (Dunnett test).
Table 1. Antinociceptive effects of acute nicotine in $\mu$-opioid receptor knock-out and wild-type mice

\begin{tabular}{lcc} 
& Wild-type mice & Knock-out mice \\
\hline Hot-plate test & & \\
$\quad$ Saline & $35.62 \pm 1.59$ & $24.42 \pm 2.39$ \\
$\quad$ Nicotine $(1 \mathrm{mg} / \mathrm{kg})$ & $50.89 \pm 3.53$ & $29.55 \pm 2.36$ \\
$\quad$ Nicotine $(3 \mathrm{mg} / \mathrm{kg})$ & $120.40 \pm 20.77$ & $48.65 \pm 4.44$ \\
Tail-immersion test & & \\
$\quad$ Saline & $0.81 \pm 0.05$ & $0.88 \pm 0.05$ \\
$\quad$ Nicotine $(1 \mathrm{mg} / \mathrm{kg})$ & $0.92 \pm 0.06$ & $0.95 \pm 0.04$ \\
Nicotine $(3 \mathrm{mg} / \mathrm{kg})$ & $1.11 \pm 0.07$ & $1.00 \pm 0.08$
\end{tabular}

Data (mean \pm SEM) obtained in the hot-plate test (jumping response in seconds) and the tail-immersion test (tail withdrawal latency in seconds) are shown.

type: $F_{(1,34)}=0.48$, NS; interaction: $F_{(1,34)}=0.05$, NS) locomotion. A lower dose of nicotine $(0.5 \mathrm{mg} / \mathrm{kg}$, s.c. $)$ did not modify locomotion even in wild-type mice.

\section{Nicotine antinociception was reduced in $\mu$-opioid receptor knock-out mice}

Nicotine-induced antinociceptive responses ( 1 and $3 \mathrm{mg} / \mathrm{kg}$, s.c.) were decreased in $\mu$-opioid receptor knock-out as compared with wild-type mice in the hot-plate and tail-immersion tests (Fig. 2, Table 1). The spontaneous nociceptive responses of both genotypes were similar in the tail-immersion test. However, the spontaneous latency of the jumping response in the hot-plate test was lower in mutant than in wild-type mice (Table 1), as reported (Matthes et al., 1998). In the hot-plate test, two-way ANOVA showed a significant effect of treatment $\left(F_{(2,54)}=20.76 ; p<\right.$ $0.0001)$, genotype $\left(F_{(1,54)}=10.99 ; p<0.01\right)$, and interaction between treatment and genotype $\left(F_{(2,54)}=6.93 ; p<0.01\right)$. Subsequent one-way ANOVA revealed significant effects of treatments in wild-type $\left(F_{(2,27)}=13.72 ; p<0.0001\right)$ and knock-out mice $\left(F_{(2,27)}=15.75 ; p<0.0001\right)$. Nicotine induced an antinociceptive response at the dose of $3 \mathrm{mg} / \mathrm{kg}(p<0.01)$ in both wild-type and knock-out mice as revealed by post hoc comparisons. Post hoc analysis also showed a reduction of nicotineinduced antinociception in $\mu$-opioid receptor knock-out when compared with wild-type mice at the doses of $1 \mathrm{mg} / \mathrm{kg}(p<0.05)$ and $3 \mathrm{mg} / \mathrm{kg}(p<0.01)$ (Fig. $2 A)$.

In the tail-immersion test, two-way ANOVA revealed a significant effect of treatment $\left(F_{(2,54)}=6.40 ; p<0.01\right)$ and no effect of genotype $\left(F_{(1,54)}=2.36\right.$; NS) or interaction between treatment and genotype $\left(F_{(2,54)}=1.24 ; \mathrm{NS}\right)$. However, subsequent one-way ANOVA (treatment) indicated a significant effect of treatment only in wild-type $\left(F_{(2,27)}=6.54 ; p<0.01\right)$ and not in knock-out mice $\left(F_{(2,27)}=1.07\right.$; NS). Post hoc comparisons showed that nicotine induced antinociception only in wild-type mice at the dose of $3 \mathrm{mg} / \mathrm{kg}(p<0.01)$ (Fig. 2B) when compared with the saline group.

\section{Nicotine did not produce rewarding responses in the place-preference paradigm in $\mu$-opioid receptor knock-out mice}

A significant rewarding effect of nicotine $(0.5 \mathrm{mg} / \mathrm{kg}$, s.c. $)$ was observed in the place-conditioning paradigm in wild-type but not in $\mu$-opioid receptor knock-out mice (Fig. $3 A$ ). Thus, two-way ANOVA indicated treatment effect $\left(F_{(1,53)}=14.96 ; p<0.001\right)$, no genotype effect $\left(F_{(1,53)}=0.0035\right.$; NS), and a significant interaction between these two factors $\left(F_{(1,53)}=6.424 ; p<0.05\right)$. Subsequent one-way ANOVA revealed that nicotine produced a 

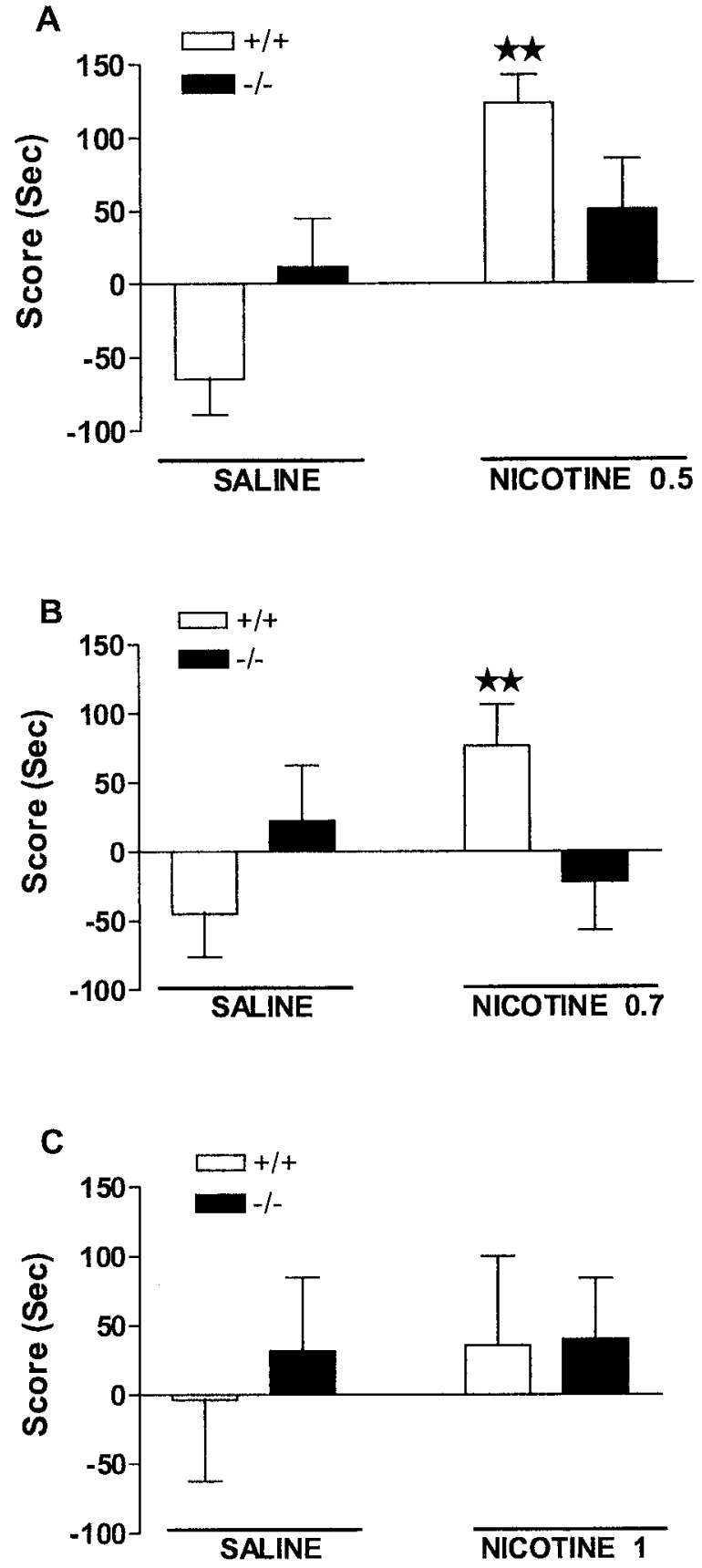

Figure 3. Rewarding effects of nicotine in $\mu$-opioid receptor knock-out and wild-type mice. Data are expressed as mean \pm SEM of score values in wild-type (white bars) and knock-out (black bars) mice $(n=10-15$ mice for each group). Nicotine was administered subcutaneously at doses of 0.5 $(A), 0.7(B)$, and $1 \mathrm{mg} / \mathrm{kg}(C)$ immediately before each conditioning session. ${ }^{\star \star} p<0.01$ when comparing with saline group of the same genotype (one-way ANOVA).

conditioned place preference for the nicotine-assigned compartment in wild-type mice $(p<0.01)$, whereas no effect was observed in knock-out mice. Nicotine administered at the dose of $0.7 \mathrm{mg} / \mathrm{kg}$ (s.c.) also produced conditioned place preference in wild-type but not in $\mu$-opioid receptor knock-out animals, as indicated by two-way ANOVA (treatment: $F_{(1,49)}=1.24$, NS; genotype: $F_{(1,49)}=0.20$, NS; interaction: $\left.F_{(1,49)}=5.76, p<0.05\right)$ (Fig. $3 B$ ). One-way ANOVA revealed a significant rewarding

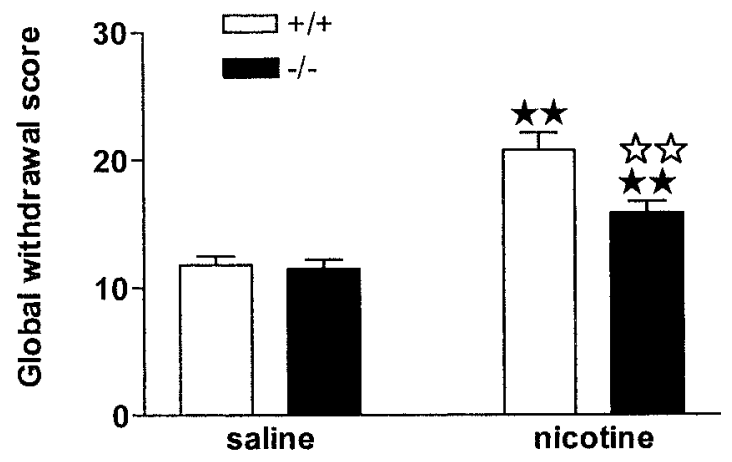

Figure 4. Mecamylamine-precipitated nicotine withdrawal in $\mu$-opioid receptor knock-out and wild-type mice. Abstinence was precipitated by acute mecamylamine administration $(1 \mathrm{mg} / \mathrm{kg}$, s.c.) after $6 \mathrm{~d}$ of nicotine perfusion $\left(10 \mathrm{mg} \cdot \mathrm{kg}^{-1} \cdot \mathrm{d}^{-1}\right)$ by using subcutaneous minipumps. A global withdrawal score was calculated for each animal by giving each individual sign a relative weight. Data are expressed as mean \pm SEM in wild-type (white bars) and knock-out (black bars) mice $(n=20-25$ mice for each group). ${ }^{\star \star} p<0.01$ when comparing with saline group of the same genotype. $p<0.01$ when comparing between genotypes (one-way ANOVA).

effect of nicotine $(0.7 \mathrm{mg} / \mathrm{kg}$, s.c. $)$ in wild-type mice $(p<0.01)$ and no effect in knock-out mice. The administration of a higher dose of nicotine $(1 \mathrm{mg} / \mathrm{kg}$, s.c.) did not induce rewarding responses in any genotype, as revealed by two-way ANOVA (treatment: $F_{(1,36)}=0.19$, NS; genotype: $F_{(1,36)}=0.128$, NS; interaction: $F_{(1,36)}=0.08$, NS) (Fig. $3 C$ ).

\section{Somatic expression of nicotine withdrawal is attenuated in $\boldsymbol{\mu}$-opioid receptor knock-out mice}

During the behavioral observation performed before mecamylamine administration, no somatic signs of withdrawal were observed in any group of animals. After mecamylamine injection, nicotine withdrawal syndrome was manifested by the presence of various somatic signs in mice receiving chronic nicotine perfusion, as reported previously (Castañé et al., 2002). The intensity of the withdrawal syndrome was decreased in $\mu$-opioid receptor knock-out mice, as shown by two-way ANOVA calculated for global withdrawal scores (treatment: $F_{(1,88)}=45.96, p<0.0001$; genotype: $F_{(1,88)}=6.97, p<0.01$; interaction: $F_{(1,88)}=5.54, p<$ $0.05)$ (Fig. 4, Table 2). Wild-type and knock-out mice receiving chronic nicotine showed significant increases in the global withdrawal scores compared with saline-treated controls $(p<0.01)$. A significant decrease of withdrawal was observed in nicotinetreated knock-out mice compared with nicotine-dependent wildtype animals $(p<0.01)$ (Fig. 4 , Table 2$)$. The most prominent sign attenuated in mutant mice was teeth chattering, as revealed by two-way ANOVA (treatment: $F_{(1,88)}=15.60, p<0.001$; genotype: $F_{(1,88)}=5.73, p<0.05$; interaction: $F_{(1,88)}=6.76, p<$ 0.05), (Table 2).

\section{DISCUSSION}

The present results clearly demonstrate the involvement of $\mu$-opioid receptors in several behavioral responses induced by nicotine and strongly support a functional interaction between nicotine and the opioid system. Thus, antinociception and nicotine withdrawal symptoms were reduced in mice lacking $\mu$-opioid receptors. Moreover, nicotine did not produce rewarding effects in these mutant mice.

Nicotine antinociception was evaluated in the tail-immersion and hot-plate tests. However, a more intense and reliable nicotine 
Table 2. Mecamylamine-precipitated nicotine withdrawal in wild-type and $\mu$-opioid receptor knock-out mice

\begin{tabular}{|c|c|c|c|c|}
\hline & \multicolumn{2}{|c|}{ Wild-type mice } & \multicolumn{2}{|c|}{ Knock-out mice } \\
\hline & Saline & Nicotine & Saline & Nicotine \\
\hline Locomotor activity & $6.45 \pm 0.51$ & $4.92 \pm 0.50$ & $6.04 \pm 0.30$ & $5.08 \pm 0.53$ \\
\hline Body tremor & $4.45 \pm 0.39$ & $5.12 \pm 0.28$ & $3.50 \pm 0.35$ & $5.08 \pm 0.24$ \\
\hline Genital licks & $1.05 \pm 0.22$ & $1.92 \pm 0.32$ & $1.04 \pm 0.23$ & $1.08 \pm 0.20$ \\
\hline Ptosis & $0.35 \pm 0.22$ & $1.52 \pm 0.32$ & $0.96 \pm 0.27$ & $1.04 \pm 0.31$ \\
\hline Wet dog shakes & $0.95 \pm 0.31$ & $1.84 \pm 0.44$ & $0.79 \pm 0.19$ & $1.69 \pm 0.36$ \\
\hline Teeth chattering & $0.40 \pm 0.13$ & $2.00 \pm 0.32$ & $0.46 \pm 0.16$ & $0.78 \pm 0.28$ \\
\hline Paw tremor & $3.35 \pm 0.69$ & $6.60 \pm 1.02$ & $2.42 \pm 0.59$ & $4.48 \pm 0.80$ \\
\hline Scratches & $1.25 \pm 0.43$ & $3.4 \pm 0.93$ & $1.70 \pm 0.62$ & $1.52 \pm 0.43$ \\
\hline Piloerection & $0.00 \pm 0.00$ & $0.76 \pm 0.28$ & $0.12 \pm 0.07$ & $0.56 \pm 0.29$ \\
\hline GWS & $11.80 \pm 0.70$ & $20.78 \pm 1.35$ & $11.52 \pm 0.71$ & $15.87 \pm 0.89$ \\
\hline
\end{tabular}

Data are expressed as mean \pm SEM. Two-way ANOVA revealed a significant effect of nicotine treatment for locomotor activity, body tremor, wet dog shakes, teeth chattering, paw tremor, piloerection, global withdrawal scores (GWS) $(p<0.01)$, and ptosis $(p<0.05)$.

antinociceptive effect was observed in the hot-plate test. The spontaneous latency of the jumping response in the hot-plate test was lower in control mutant than in wild-type mice, indicating a higher sensitivity of $\mu$-opioid receptor-deficient mice to painful stimuli in these experimental conditions, as reported previously (Matthes et al., 1998). Nicotine-induced antinociception in the hot-plate test was significantly reduced in $\mu$-opioid receptor knock-out mice, suggesting that this receptor is recruited to produce nicotine antinociception. The reduced jumping response observed in knock-out mice cannot be attributed to a motor impairment. Indeed, the spontaneous locomotion and nicotinedecreased locomotion were similar in both genotypes. In agreement with our results, several studies have reported that the opioid system could play a role in modulating nicotine antinociception. Thus, naloxone decreased nicotine-induced antinociception in the formalin test (Zarrindast et al., 1997) as well as the potentiation of this effect elicited by the coadministration of nicotine and morphine in the tail-flick test (Zarrindast et al., 1996). In support of these pharmacological data, molecular studies have shown that acute nicotine increases preproenkephalin mRNA levels in rat striatum and hippocampus (Houdi et al., 1998), and chronic nicotine decreases met-enkephalin levels in the rat striatum and develops tolerance to antinociception (Wewers et al., 1999). Interestingly, this last study also reported an upregulation of $\mu$-opioid receptors to compensate for the reduction in met-enkephalin contents after chronic nicotine. Taken together, these data indicate a role of $\mu$-opioid receptors in nicotine-induced antinociception. Furthermore, the colocalization of $\mathrm{nAChRs}$ and $\mu$-opioid receptors in several central structures related to supraspinal and spinal nociceptive control, such as thalamus and the dorsal horn of the spinal cord (Mansour et al., 1995; Marubio et al., 1999), suggests the hypothesis of an interaction between nicotine and $\mu$-opioid receptors to regulate nociception. In contrast with the present results on antinociception, nicotine produced the same decrease in locomotion in both wildtype and mutant mice. This topic was not investigated previously by pharmacological studies.

Nicotine, like other drugs of abuse, activates the mesocorticolimbic dopamine system (Pontieri et al., 1996) and induces rewarding properties in rodents (Picciotto et al., 1998). Nicotine produces conditioned place preference only under a narrow range of doses. Indeed, nicotine rewarding properties show a bellshaped curve pattern in the place-preference paradigm. Thus, intermediate doses are effective, low doses are ineffective, and high doses are ineffective or even aversive (Risinger and Oakes, 1995). Nicotine did not induce rewarding effects in any genotype at the dose of $1 \mathrm{mg} / \mathrm{kg}$, but it produced a clear place preference in wild-type mice when administered at the dose of $0.5 \mathrm{mg} / \mathrm{kg}$, as reported previously (Risinger and Oakes, 1995; Castañé et al., 2002). At the dose of $0.7 \mathrm{mg} / \mathrm{kg}$, nicotine also induced rewarding effects in wild-type animals. However, these effective doses of nicotine failed to reveal any conditioned response in mice lacking $\mu$-opioid receptors. The absence of rewarding effects observed in knock-out mice cannot be attributed to a locomotor inhibition because a similar decrease of locomotor activity was induced by nicotine at the dose of $0.7 \mathrm{mg} / \mathrm{kg}$ in both genotypes. $\mu$-Opioid receptors also seem to be crucial in mediating rewarding properties of other drugs of abuse such as morphine (Matthes et al., 1996), ethanol (Roberts et al., 2000), and $\Delta^{9}$-tetrahydrocannabinol (Ghozland et al., 2002). However, $\mu$-opioid receptor knock-out mice did not present a general impairment in the performance for rewarding stimuli. Indeed, the same line of $\mu$-opioid receptor knock-out mice showed an appropriate learning to respond for food reward in an operant paradigm (Roberts et al., 2000). A possible interaction on dopaminergic mesolimbic activity could explain the present findings because nAChRs and $\mu$-opioid receptors are highly expressed in these areas (Mansour et al., 1995; Picciotto et al., 1998). In addition, the activation of both $\mu$-opioid receptors and nAChRs induces release of dopamine in the shell of the nucleus accumbens (Pontieri et al., 1996). However, the pharmacological approach failed to reveal this nicotine/opioid interaction when using the self-administration paradigm (Corrigall and Coen, 1991).

Finally, nicotine abstinence was precipitated by mecamylamine in chronic nicotine-treated mice. Previous studies have characterized the behavioral manifestations of nicotine withdrawal in rodents (Hildebrand et al., 1999; Castañé et al., 2002). Some common mechanisms underlying opioid and nicotine dependence have been suggested recently (Malin, 2001). Thus, the opioid antagonist naloxone is able to precipitate withdrawal after chronic nicotine treatment (Malin et al., 1993), whereas morphine attenuates spontaneous nicotine withdrawal (Malin et al., 1993). Conversely, nicotine also reduces naloxone-precipitated morphine withdrawal (Zarrindast and Farzin, 1996). In addition, the opioid antagonist naltrexone has been shown to reduce the tobacco consumption rate and satisfaction with smoking in humans (Wewers et al., 1998). In our experimental conditions, we have observed an attenuation of the somatic expression of nicotine 
withdrawal in the absence of $\mu$-opioid receptors, indicating that these receptors could modulate nicotine physical dependence. Although further experiments will be necessary to elucidate the nature of this interaction, the release of endogenous opioids by $\mathrm{nAChR}$ stimulation and subsequent activation of $\mu$-opioid receptors could explain at least some of these findings.

In conclusion, our data clearly demonstrate an involvement of the opioid system, through $\mu$ receptors, in modulating some behavioral responses induced by nicotine and improve the understanding of the neurobiological bases of nicotine addiction.

\section{REFERENCES}

Almeida LE, Pereira EF, Alkondon M, Fawcett WP, Randall WR, Albuquerque EX (2000) The opioid antagonist naltrexone inhibits activity and alters expression of $\alpha 7$ and $\alpha 4 \beta 2$ nicotinic receptors in hippocampal neurons: implications for smoking cessation programs. Neuropharmacology 39:2740-2755.

Balfour DJ (1982) The effects of nicotine on brain neurotransmitter systems. Pharmacol Ther 16:269-282.

Castañé A, Valjent E, Ledent C, Parmentier M, Maldonado R, Valverde O (2002) Lack of $\mathrm{CB}_{1}$ cannabinoid receptors modifies nicotine behavioural responses, but not nicotine abstinence. Neuropharmacology 43:857-867.

Clarke PBS, Reuben M (1996) Release of $\left[{ }^{3} \mathrm{H}\right]$-noradrenaline from rat hippocampal synaptosomes by nicotine: mediation by different nicotinic receptor subtypes from striatal $\left[{ }^{3} \mathrm{H}\right]$-dopamine release. $\mathrm{Br} \mathrm{J}$ Pharmacol 117:595-606

Corrigall WA, Coen KM (1991) Opiate antagonists reduce cocaine but not nicotine self-administration. Psychopharmacology 104:167-170.

Crooks PA, Dwoskin LP (1997) Contribution of CNS nicotine metabolites to the neuropharmacological effects of nicotine and tobacco smoking. Biochem Pharmacol 54:743-753.

Dani JA (2001) Overview of nicotinic receptors and their roles in the central nervous system. Biol Psychiatry 49:166-174.

Decker MW, Meyer MD (1999) Therapeutic potential of neuronal nicotinic acetylcholine receptor agonists as novel analgesics. Biochem Pharmacol 58:917-923.

Decker MW, Brioni ID, Bannon AW, Arneric SP (1995) Diversity of neuronal nicotinic acetylcholine receptors: lessons from behavior and implications for CNS therapeutics. Life Sci 56:545-570.

Dhatt RK, Gudehithlu KP, Wemlinger TA, Tejwani GA, Neff NH, Hadjiconstantinou M (1995) Preproenkephalin mRNA and methionine-enkephalin content are increased in mouse striatum after treatment with nicotine. J Neurochem 64:1878-1883.

Ghozland S, Matthes HW, Simonin F, Filliol D, Kieffer BL, Maldonado R (2002) Motivational effects of cannabinoids are mediated by $\mu$-opioid and $\kappa$-opioid receptors. J Neurosci 22:1146-1154.

Hildebrand BE, Panagis G, Svensson TH, Nomikos GG (1999) Behavioral and biochemical manifestations of mecamylamine-precipitated nicotine withdrawal in the rat: role of nicotinic receptors in the ventral tegmental area. Neuropsychopharmacology 21:560-574.

Houdi AA, Dasgupta R, Kindy MS (1998) Effect of nicotine use and withdrawal on brain preproenkephalin A mRNA. Brain Res 799: 257-263.

Hutcheson DM, Matthes HW, Valjent E, Sánchez-Blázquez P, Rodríguez-Díaz M, Garzón J, Kieffer BL, Maldonado R (2001) Lack of dependence and rewarding effects of deltorphin II in $\mu$-opioid receptor-deficient mice. Eur J Neurosci 13:153-161.

Karras A, Kane JM (1980) Naloxone reduces cigarette smoking. Life Sci 27:1541-1545.

Kieffer BL (1999) Opioids: first lessons from knock-out mice. Trends Pharmacol Sci 20:19-26.

Malin DH (2001) Nicotine dependence. Studies with a laboratory model. Pharmacol Biochem Behav 70:551-559.

Malin DH, Lake JR, Carter VA, Cunningham JS, Wilson OB (1993)
Naloxone precipitates nicotine abstinence syndrome in the rat. Psychopharmacology 112:339-342.

Mansour A, Fox CA, Akil H, Watson SJ (1995) Opioid-receptor mRNA expression in the rat CNS: anatomical and functional implications. Trends Neurosci 18:22-29.

Marubio LM, del Mar Arroyo-Jimenez M, Cordero-Erausquin M, Lena C, Le Novere M, de Kerchove d'Exaerde A, Huchet M, Damaj MI, Changeux JP (1999) Reduced antinociception in mice lacking neuronal nicotinic receptor subunits. Nature 398:805-810.

Matthes HW, Maldonado R, Simonin F, Valverde O, Slowe S, Kitchen I, Befort K, Dierich A, Le Meur M, Dolle P, Tzavara E, Hanoune J, Roques BP, Kieffer BL (1996) Loss of morphine induced-analgesia, reward effect and withdrawal symptoms in mice lacking the mu-opioidreceptor gene. Nature 383:819-823.

Matthes HW, Smadja C, Valverde O, Vonesch JJ, Foutz AS, Boudinot E, Denavit-Saubie M, Severini C, Negri L, Roques BP, Maldonado R, Kieffer BL (1998) Activity of the $\delta$-opioid receptor is partially reduced while activity of the $\kappa$-receptor is maintained in mice lacking the $\mu$-receptor. J Neurosci 18:7285-7295.

McGehee DS, Heath MJ, Gelber S, Devay P, Role LW (1995) Nicotine enhancement of fast excitatory synaptic transmission in CNS by presynaptic receptors. Science 269:1692-1696.

Picciotto MR, Zoli M, Rimondini R, Lena C, Marubio LM, Pich EM, Fuxe K, Changeux JP (1998) Acetylcholine receptors containing the beta2 subunit are involved in the reinforcing properties of nicotine. Nature 391:173-177.

Pontieri FE, Tanda G, Orzi F, Di Chiara G (1996) Effects of nicotine on the nucleus accumbens and similarity to those of addictive drugs. Nature 382:255-257.

Risinger FO, Oakes RA (1995) Nicotine-induced conditioned place preference and conditioned place aversion in mice. Pharmacol Biochem Behav 51:457-461.

Roberts AJ, McDonal JS, Heyser CJ, Kieffer BL, Matthes HW, Koob GF, Gold LH (2000) $\mu$-Opioid receptor knockout mice do not selfadminister alcohol. J Pharmacol Exp Ther 293:1002-1008.

Simonin F, Valverde O, Smadja C, Slowe S, Kitchen I, Dierich A, Le Meur M, Roques BP, Maldonado R, Kieffer BL (1998) Disruption of the kappa-opioid receptor gene in mice enhances sensitivity to chemical visceral pain, impairs pharmacological actions of the selective kappa-agonist U-50, 488 $\mathrm{H}$ and attenuates morphine withdrawal. EMBO J 17:886-897.

Tome AR, Izaguirre V, Rosario LM, Cena V, Gonzalez-Garcia G (2001) Naloxone inhibits nicotine-induced receptor current and catecholamine secretion in bovine chromaffin cells. Brain Res 903:62-65.

Watkins SS, Stinus L, Koob GF, Markou A (2000) Reward and somatic changes during precipitated nicotine withdrawal in rats: centrally and peripherally mediated effects. J Pharmacol Exp Ther 292:1053-1064.

Wewers ME, Dhatt R, Tejwani GA (1998) Naltrexone administration affects ad libitum smoking behavior. Psychopharmacology 140:185-190.

Wewers ME, Dhatt RK, Snively TA, Tejwani GA (1999) The effect of chronic administration of nicotine on antinociception, opioid receptor binding and met-enkephalin levels in rats. Brain Res 822:107-113.

Wilkie GI, Hutson PH, Stephens MW, Whiting P, Wonnacott S (1993) Hippocampal nicotinic autoreceptors modulate acetylcholine release. Biochem Soc Trans 21:429-431.

Yang X, Criswell HE, Breese GR (1996) Nicotine-induced inhibition in medial septum involves activation of presynaptic nicotinic cholinergic receptors on gamma-aminobutyric acid-containing neurons. J Pharmacol Exp Ther 276:482-489.

Zarrindast MR, Farzin D (1996) Nicotine attenuates naloxone-induced jumping behavior in morphine-dependent mice. Eur J Pharmacol 298:1-6.

Zarrindast MR, Nami AB, Farzin D (1996) Nicotine potentiates morphine antinociception: a possible cholinergic mechanism. Eur Neuropsychopharmacol 6:127-133.

Zarrindast MR, Pazouki M, Nassiri-Rad S (1997) Involvement of cholinergic and opioid receptor mechanisms in nicotine-induced antinociception. Pharmacol Toxicol 81:209-213. 